\title{
Amphiphysin I Antisense Oligonucleotides Inhibit Neurite Outgrowth in Cultured Hippocampal Neurons
}

\author{
Olaf Mundigl, ${ }^{1}$ Gian-Carlo Ochoa, ${ }^{1}$ Carol David, ${ }^{1}$ Vladimir I. Slepnev, ${ }^{1}$ Alexander Kabanov, ${ }^{2}$ and \\ Pietro De Camilli ${ }^{1}$ \\ ${ }^{1}$ Department of Cell Biology and Howard Hughes Medical Institute, Yale University School of Medicine, Boyer Center for \\ Molecular Medicine, New Haven, Connecticut 06510, and 2Department of Pharmaceutical Sciences, University of \\ Nebraska Medical Center, Omaha, Nebraska 68198
}

\begin{abstract}
Amphiphysin I is an $\mathrm{SH} 3$ domain-containing neuronal protein, enriched in axon terminals, which was reported to act as a physiological binding partner for dynamin I in synaptic vesicle endocytosis. Rvs167 and Rvs161, the yeast homologs of amphiphysin I, have been implicated in endocytosis, actin function, and cell polarity. Now we have explored the possibility that amphiphysin I also may have a role in actin dynamics and cell polarity by testing the effect of amphiphysin I suppression on neurite outgrowth. Freshly plated hippocampal neurons were exposed to antisense oligonucleotides via a new delivery system based on a polycationic amphipathic polymer, PS980. Western blot analysis revealed that amphiphysin I levels steadily increased with neuronal differentiation, whereas in antisense-treated cultures amphiphysin I levels were reduced
\end{abstract}

to $\sim 10 \%$ of control levels at $48 \mathrm{hr}$. Concomitantly, a collapse of growth cones and a severe inhibition of neurite outgrowth and axon formation were observed. A similar effect was observed previously after dynamin I suppression in the same culture system (Torre et al., 1994). We also have found that amphiphysin I and dynamin I colocalize in developing neurons at all developmental stages and that a pool of both proteins is colocalized with actin patches at the leading edge of growth cones. Our findings suggest a conserved role of the amphiphysin protein family in the dynamics of the cortical cell cytoskeleton and provide new evidence for a close functional link between amphiphysin I and dynamin I.

Key words: Rvs; endocytosis; synaptic vesicles; actin; dynamin; synaptojanin; growth cones
Amphiphysin I is a neuronal cytosolic protein concentrated in nerve terminals, which was identified independently as an antigen enriched in chicken synaptic membranes (Lichte et al., 1992), and as the dominant autoantigen in a rare human condition, paraneoplastic stiff-man syndrome (De Camilli et al., 1993; Folli et al., 1993; David et al., 1994). It comprises an NH2 terminal region, which has the potential to form coiled-coil structures (David et al., 1994; Sivadon et al., 1995), a central region, which is evolutionarily poorly conserved (Lichte et al., 1992; David et al., 1994), and a COOH-terminal SH3 domain (David et al., 1994). It is a member of a protein family that includes at least another member in higher vertebrates, referred to as amphiphysin II (BIN1, SH3p9) (Sakamuro et al., 1996; Sparks et al., 1996; Butler et al., 1997; Leprince et al., 1997), and two members in yeast, the Rvs167 and Rvs161 proteins (Crouzet et al., 1991; David et al., 1994; Sivadon et al., 1995).

Recent studies have suggested that amphiphysin I is a physiological partner of dynamin I, a GTPase that plays a key role in the endocytotic reaction of synaptic vesicle membranes (for review, see De Camilli and Takei, 1996). Dynamin I binds the SH3

Received June 26, 1997; revised Oct. 14, 1997; accepted Oct. 15, 1997.

This work was supported by grants from the Donaghue Foundation, the Human Frontier Science Program, and the National Institutes of Health (CA46128) to P.D.C.; by a postdoctoral fellowship from the Muscular Dystrophy Association to V.I.S.; and by the United States Army Medical Research and Development Command to C.D. We thank Laurie Daniell for outstanding technical support. We also thank the W. M. Keck Facility at Yale University for oligonucleotide synthesis.

Correspondence should be addressed to Dr. Pietro De Camilli, Department of Cell Biology, Howard Hughes Medical Institute, Yale University School of Medicine, Boyer Center for Molecular Medicine, 295 Congress Avenue New Haven, CT 06510 .

Copyright (C) 1997 Society for Neuroscience $\quad 0270-6474 / 97 / 180093-11 \$ 05.00 / 0$ domain of amphiphysin I via its proline-rich COOH-terminal domain (David et al., 1996; Grabs et al., 1997). Temperaturesensitive mutations of the dynamin I gene in Drosophila (shibire gene) produce a powerful temperature-sensitive block in synaptic vesicle recycling at the stage of deeply invaginated plasmalemmal pit (Koenig and Ikeda, 1989). Dynamin oligomerizes into ringlike structures at the neck of endocytotic pits, and the nonhydrolyzable analog of GTP, GTP $\gamma$ s, has been shown to stabilize these rings and to prevent the fission reaction (Koenig and Ikeda, 1989; Hinshaw and Schmid, 1995; Takei et al., 1995, 1996).

The hypothesis that the interaction of amphiphysin I with dynamin I occurs in situ and is important for the function of dynamin I is supported by a variety of studies. First, amphiphysin I and dynamin I have a similar distribution in the brain, where both are concentrated at synapses (Lichte et al., 1992; David et al., 1996). Second, pools of dynamin I and amphiphysin I can be coprecipitated from brain extracts (David et al., 1996) and undergo parallel dephosphorylation after nerve terminal stimulation (Robinson et al., 1993; Bauerfeind et al., 1998). Third, disruption of the interaction of the proline-rich tail of dynamin I with SH3 domains, including the SH3 domain of amphiphysin I, produces an impairment of synaptic vesicle endocytosis at the stage of deeply invaginated clathrin-coated pits (Shupliakov et al., 1997), i.e., the stage at which the action of dynamin I has been implicated (Koenig and Ikeda, 1989). There is evidence to suggest that amphiphysin I acts upstream of dynamin and is important in its recruitment to sites of endocytosis (Shupliakov et al., 1997).

In agreement with these results, genetic studies in yeast have demonstrated a role of the RVS genes in endocytosis (Munn et al., 

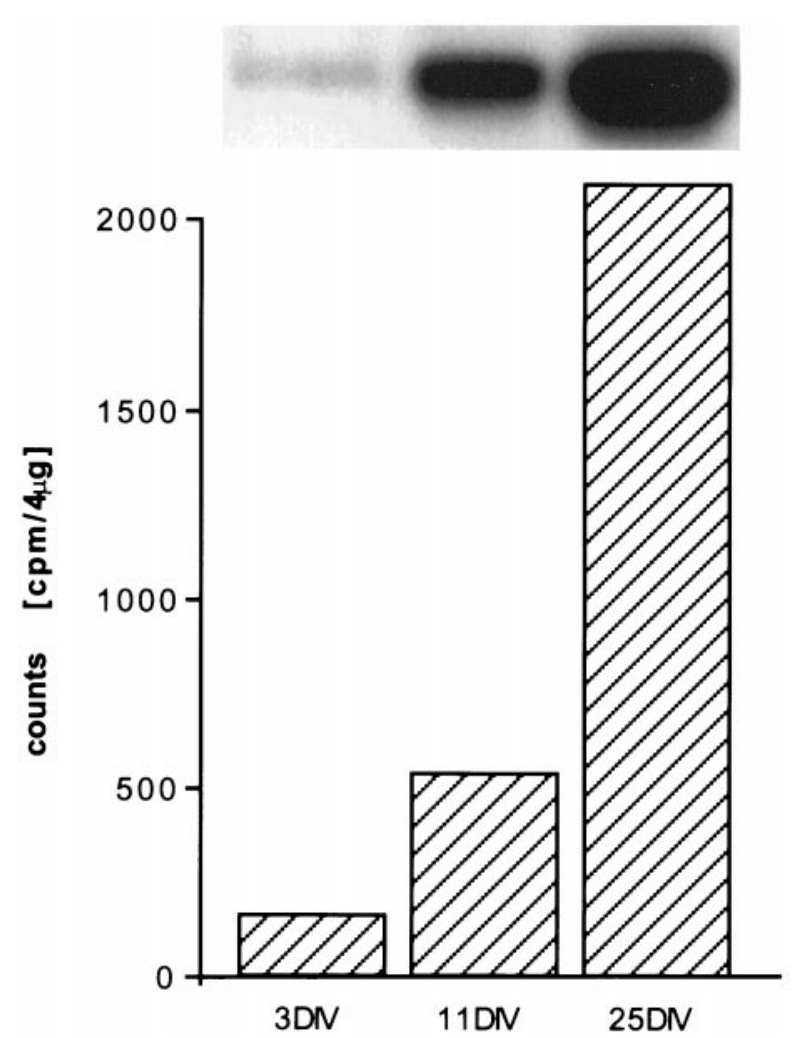

Figure 1. Amphiphysin I expression is upregulated during the development of hippocampal neurons in vitro. Shown is a Western blot analysis (using ${ }^{125}$ I-Protein $\mathrm{A}$ as an antibody detector) of homogenates from cultures after 3,11 , and $25 \mathrm{~d}$ in vitro. This time course correlates with the growth of neurites and the formation of synapses in these cultures. Equal amounts of total protein were added to each lane. Amphiphysin immunoreactivity was detected by autoradiography (top) or measured in a gamma counter (bottom).

1995). In addition, yeast genetic studies also have implicated the RVS genes in actin function and cell polarity (Munn et al., 1995; Sivadon et al., 1995). Whether a similar link exists between amphiphysin family members and actin in higher vertebrates remains unclear, although recent studies on amphiphysin II suggest pleotropic roles of this protein (Sakamuro et al., 1996; Butler et al., 1997; Leprince et al., 1997), including roles in clathrinmediated endocytosis and in cortical actin function (Butler et al., 1997; Ramjaun et al., 1997).

In vitro studies on neurons of shibire mutants of Drosophila have shown that they display an impairment of neurite outgrowth at the restrictive temperature (Masur et al., 1990). Furthermore, suppression of dynamin I expression by antisense oligonucleotides in cultured hippocampal neurons and neuroblastoma cells was found to produce a potent inhibition of neurite formation and the collapse of growth cones (Torre et al., 1994). These findings indicate a critical role for dynamin I in neuritogenesis, although its mechanism of action in growth cone dynamics remains unclear. The role of dynamin I in neurite formation may be the consequence of an endocytotic block. However, it is possible that dynamin I suppression also may have a negative effect on the actin cytoskeleton. For example, transfection of a dominant negative mutant dynamin in fibroblastic cells was found to inhibit actin dynamics at the cell periphery (Damke et al., 1994). If amphiphysin I is a physiological upstream partner of dynamin I, it may be expected that amphiphysin I also may be required in growth cone dynamics. This action would be consistent with the known role of the yeast Rvs proteins in actin function and polarized growth.

We show here that suppression of amphiphysin I by antisense oligonucleotides has a potent inhibitory effect on neurite outgrowth, as previously shown for dynamin I suppression (Torre et al., 1994). We also report that amphiphysin I and dynamin I are closely colocalized with each other and in turn colocalize with actin patches in growth cones of developing neurons. These findings suggest that, similar to its yeast homologs, amphiphysin I may have pleotropic roles in endocytosis, actin function, and cell polarity.

\section{MATERIALS AND METHODS}

Antibodies and reagents. The following antibodies were raised in our laboratory: rabbit and mouse polyclonal antibodies directed against fulllength amphiphysin (David et al., 1996), rabbit polyclonal antibodies against synapsin I (De Camilli et al., 1983a), rabbit polyclonal antibodies against human dynamin I (DG-1) (Butler et al., 1997), and rabbit polyclonal antibodies against luminal domain of synaptotagmin (Mundigl et al., 1995). A monoclonal antibody directed against syntaxin 1 (HPC-1) was a kind gift from Dr. C. Barnstable (Yale University, New Haven, $\mathrm{CT}$ ). Monoclonal antibodies directed against dynamin I (Hudy-1) and $\beta$-tubulin were purchased from Upstate Biotechnology (Lake Placid, NY) and Sigma (St. Louis, MO), respectively. MAP2 and actin antibodies were purchased from Boehringer Mannheim (Indianapolis, IN). Rhodamine- and fluorescein-labeled phalloidin was purchased from Molecular Probes (Eugene, OR). Secondary antibodies conjugated with CY3, DTAF, and cascade blue were purchased from Jackson ImmunoResearch (West Grove, PA) and Molecular Probes.

Antisense oligonucleotides. All oligonucleotides used in this study were unmodified phosphodiester oligonucleotides synthesized in the W. M. Keck facility at Yale University. Two amphiphysin antisense oligonucleotide constructs, termed AMAS3 (5'-GCTGCGGGTCCGGGGAGC TG- $3^{\prime}$ ) and AMAS4 (5'-GAGCTGCGAGAGCAGAGCG-3'), were designed on the basis of the amphiphysin cDNA sequence. Control sense constructs were synthesized as the reverse complement of the antisense oligonucleotides. An oligo termed AMAS.3.SCR (5'-GCGTGTTGCGG GCGCCAGGG- $3^{\prime}$ ) was designed to contain the same content of nucleotides as AMAS3 but in a random order. The sequences did not match any other known gene listed in the database. To facilitate the uptake of the oligonucleotides into cells, we complexed them at a stoichiometry of 1:1 with cationic copolymer molecules (PS980) that were shown to enhance cell entry and possibly the stability of small nucleic acid fragments (Kabanov et al., 1995). PS980 copolymer was provided by Supratek Pharma (Montréal, Québec, Canada). These molecules consist of a poly(ethylene oxide) and positively charged poly(spermine) segment. They spontaneously form complexes with oligonucleotides in which the charges of the poly(spermine) segment and DNA are neutralized. Despite the charge neutralization, the complexes remain in solution because of the solubilizing effect of the poly(ethylene oxide). The complexes are thought to self-assemble into uncharged micelles with $\mathrm{cmc}$ in the micromolar range (Kabanov et al., 1995, 1996). Oligonucleotides were applied at the final concentration of $1.0 \mu \mathrm{M}$ in fresh glia-conditioned "neuronal" medium. Initially, the optimal oligonucleotide concentration was determined by applying $0.5,1.0$, and $2.0 \mu \mathrm{M}$. These complexes produced suppression of the target gene at final oligonucleotide concentrations in the range of $1 \mu \mathrm{M}$, which were 50-100 times lower that when oligonucleotides were used alone (Vinogradov et al., 1994).

Hippocampal cell cultures. A monolayer of cortical glial cells was grown as described (Banker and Cowan, 1977; Goslin and Banker, 1990). Neuronal cultures were prepared essentially as described by Banker and Cowan (1977). Briefly, hippocampi from 18-d-old fetal rats were dissociated by treatment with trypsin $\left(0.25 \%\right.$ for $15 \mathrm{~min}$ at $\left.37^{\circ} \mathrm{C}\right)$, followed by trituration with a fire-polished Pasteur pipette. Dissociated cells were plated on poly-L-lysine-treated glass coverslips in MEM with $10 \%$ horse serum at densities ranging from 3000 to 25,000 cells $/ \mathrm{cm}^{2}$. After $4 \mathrm{hr}$ the coverslips were transferred, face down, to dishes containing the monolayer of cortical glial cells in neuronal medium MEM (Life Technologies, Gaithersburg, MD) without sera, supplemented with 1\% HL1 (Ventrex, Portland, ME), $2 \mathrm{~mm}$ glutamine, and $1 \mathrm{mg} / \mathrm{ml}$ BSA. For treatment with sense or antisense oligonucleotides, coverslips with freshly plated neurons were transferred to 12 well plates devoid of glia and were incubated in glia-conditioned medium. The medium was replaced every $12 \mathrm{hr}$ with 

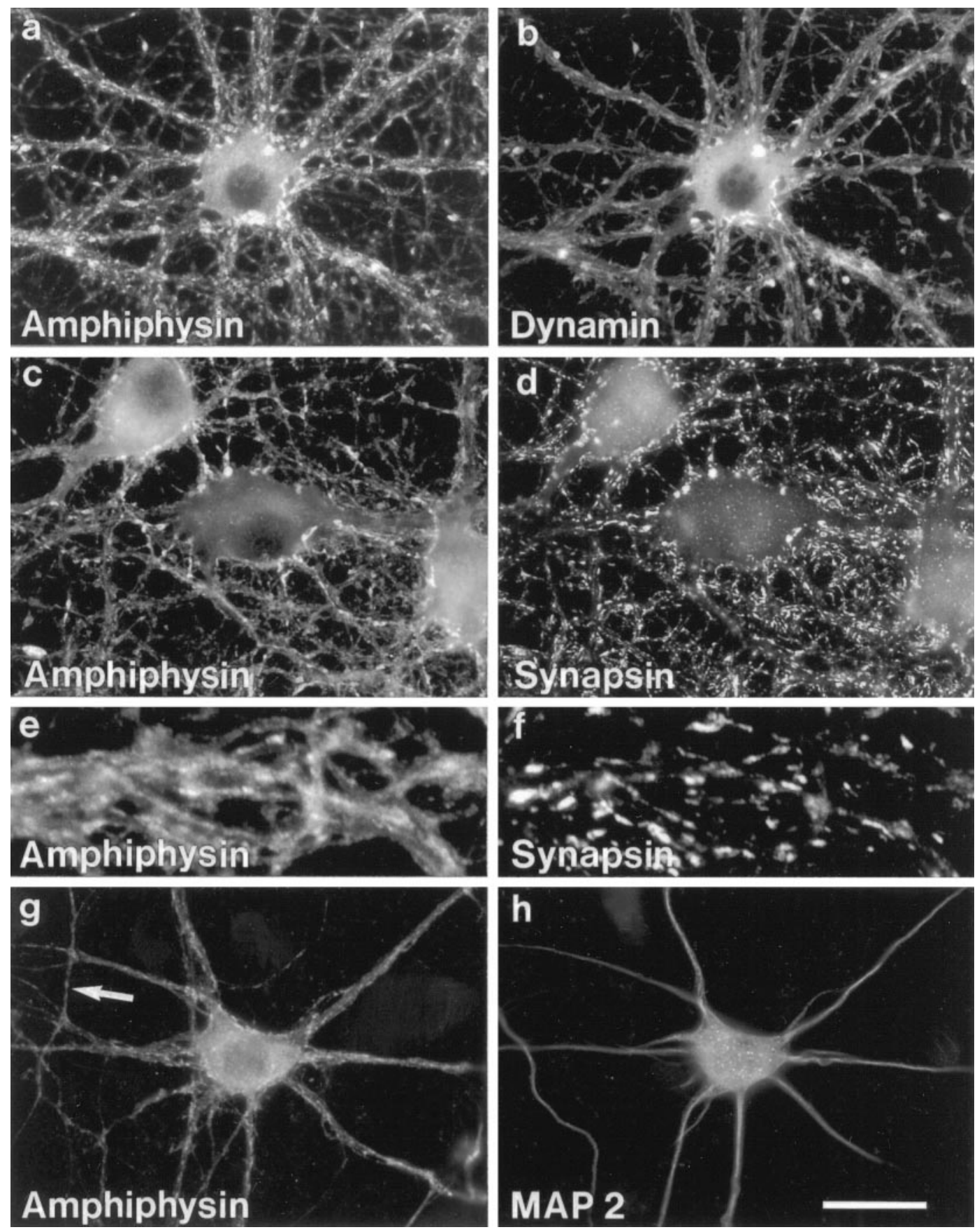

Figure 2. Concentration of both amphiphysin I and dynamin I at presynaptic contacts in mature hippocampal cultures (2-3 weeks in vitro). $a, b$, Double immunofluorescence for amphiphysin I and dynamin I. Both proteins are concentrated at "hot spots" along the perikaryal and dendritic surface of the neuron shown in the field. $c-f$, Double immunofluorescence for amphiphysin I and for the synaptic vesicle marker synapsin I, demonstrating that amphiphysin I immunoreactivity is not restricted to synaptic vesicle clusters but extends to interconnecting axonal segments. $g$, $h$, Double immunofluorescence for amphiphysin I and for the dendritic marker MAP2 further illustrating that low levels of amphiphysin are also present in nonsynaptic regions of axons (arrow). Scale bar: for $a-d, g, h, 18.6 \mu \mathrm{m}$; for $e, f, 9.3 \mu \mathrm{m}$.

fresh oligonucleotide containing conditioned medium. Glia-conditioned medium was prepared by adding neuronal medium to sets of gliacontaining dishes $12 \mathrm{hr}$ before neuronal plating. The medium of one of this dishes was used for each change.

Immunocytochemistry. Cultures were fixed by $4 \%$ formaldehyde (freshly prepared from paraformaldehyde) in $0.1 \mathrm{M}$ phosphate buffer containing $0.12 \mathrm{M}$ sucrose, detergent-permeabilized, immunostained, and prepared for microscopic observation as previously described (De Camilli et al., 1983a; Cameron et al., 1991). For triple labeling, the primary antibodies were applied together with fluorescein-labeled phalloidin and detected with CY3 and cascade blue-conjugated secondary antibodies.
Pictures were taken with T-MAX 100 (Kodak, Rochester, NY) film at a Zeiss Axiophot microscope (Oberkochen, Germany) equipped with epifluorescence microscopy.

Western blot analysis and protein determination. Neurons on coverslips were rinsed in warm Krebs'-Ringer's-HEPES buffer and then scraped off the coverslip directly into Laemmli sample buffer for SDS-PAGE. Total protein was determined with the NanoOrange protein assay (Molecular Probes) after solubilization of the neurons from coverslips by exposure to $95^{\circ} \mathrm{C}$ for $10 \mathrm{~min}$ in NanoOrange protein reagent. SDS-PAGE was performed according to Laemmli (1970). Transfer of the proteins to nitrocellulose membranes (Millipore, Bedford, MA) and Western blot 


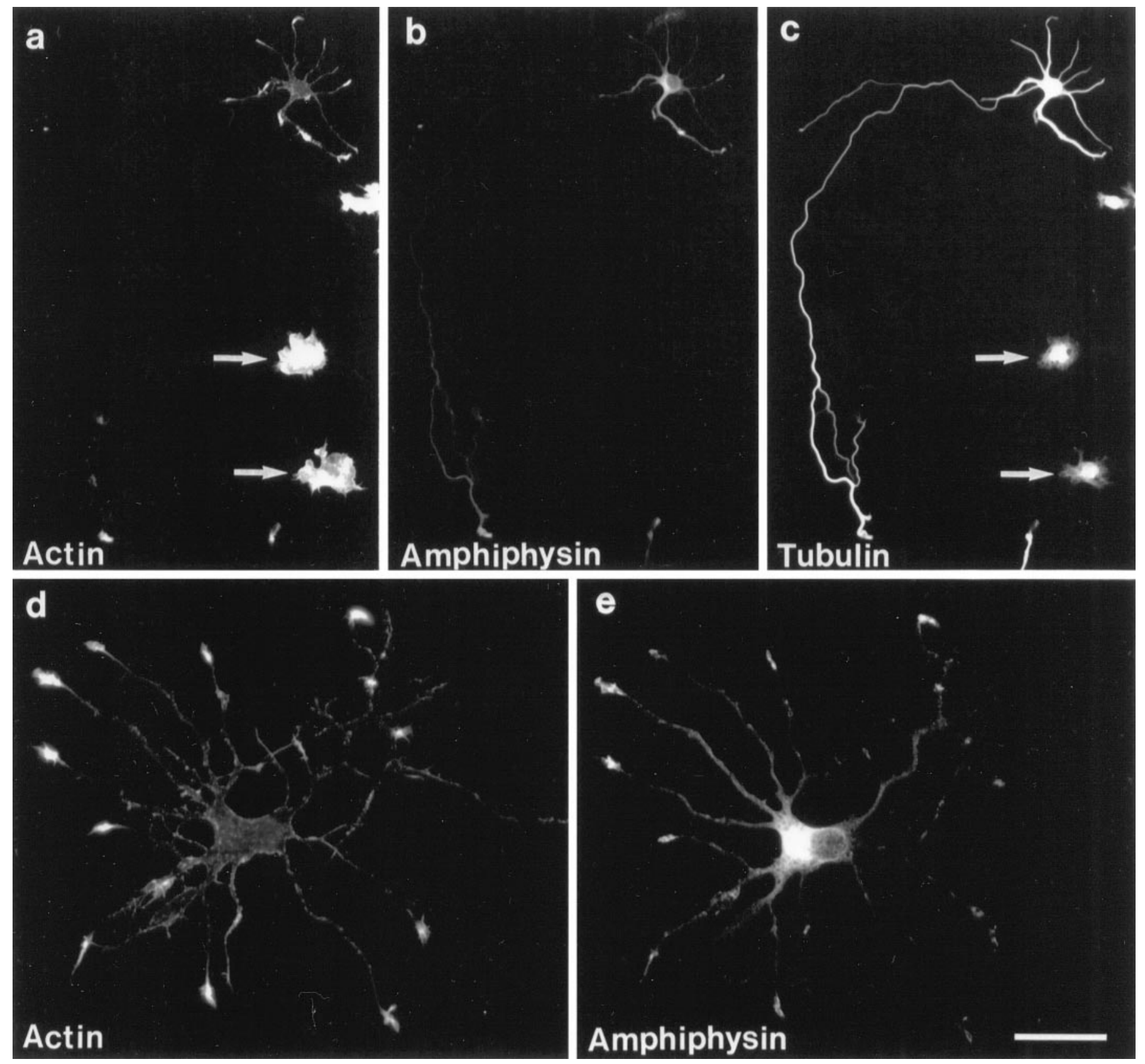

Figure 3. Distribution of amphiphysin I in cultured hippocampal neurons developing in isolation (stage 3 neurons). $a-c$, Low-power view of a neuron triple-stained for F-actin (TRITC phalloidin), amphiphysin (DTAF), and tubulin (cascade blue). Amphiphysin I is concentrated in the perikaryon and distal actin-rich portion of the axon and dendrites. Amphiphysin I (a neuron-specific protein) is absent from two glial cells visible in the field (arrows). $d, e$, High-power view of the somatodendrite region of a neuron double-stained for F-actin (TRITC phalloidin) and amphiphysin I (DTAF). Note the striking colocalization of amphiphysin and actin in the growth cones of all processes. Scale bar: for $a-c, 72 \mu \mathrm{m} ;$ for $d, e, 26.3 \mu \mathrm{m}$.

analysis (Kyhse-Andersen, 1994) that used ${ }^{125}$ I-Protein A (Amersham, Arlington Heights, IL) or ECL were performed as described.

Transferrin uptake. Hippocampal cultures were treated with CY3conjugated human transferrin $(20 \mu \mathrm{g} / \mathrm{ml}$ final concentration) for $20 \mathrm{~min}$ at $37^{\circ}$ in culture medium and then rinsed in the same buffer and fixed as described above.

\section{RESULTS}

\section{Amphiphysin I expression in cultured} hippocampal neurons

As a premise to the study of the properties of amphiphysin I in growth cones of hippocampal neurons in vitro, we investigated the pattern of expression of this protein during neuronal development. Figure 1 shows the Western blot analysis of homogenates from hippocampal cultures harvested after various days in vitro (DIV). Amphiphysin I is expressed, and its level increases $\sim 10$-fold between 3 and 25 DIV. This increase parallels the time course of neurite outgrowth and synaptogenesis and is consistent with an important role of amphiphysin I in neurite elongation and presynaptic function in hippocampal neurons.

Immunofluorescence staining of mature cultures rich in synaptic contacts revealed that both amphiphysin I and dynamin I are concentrated along the surface of perikarya and dendrites, where 

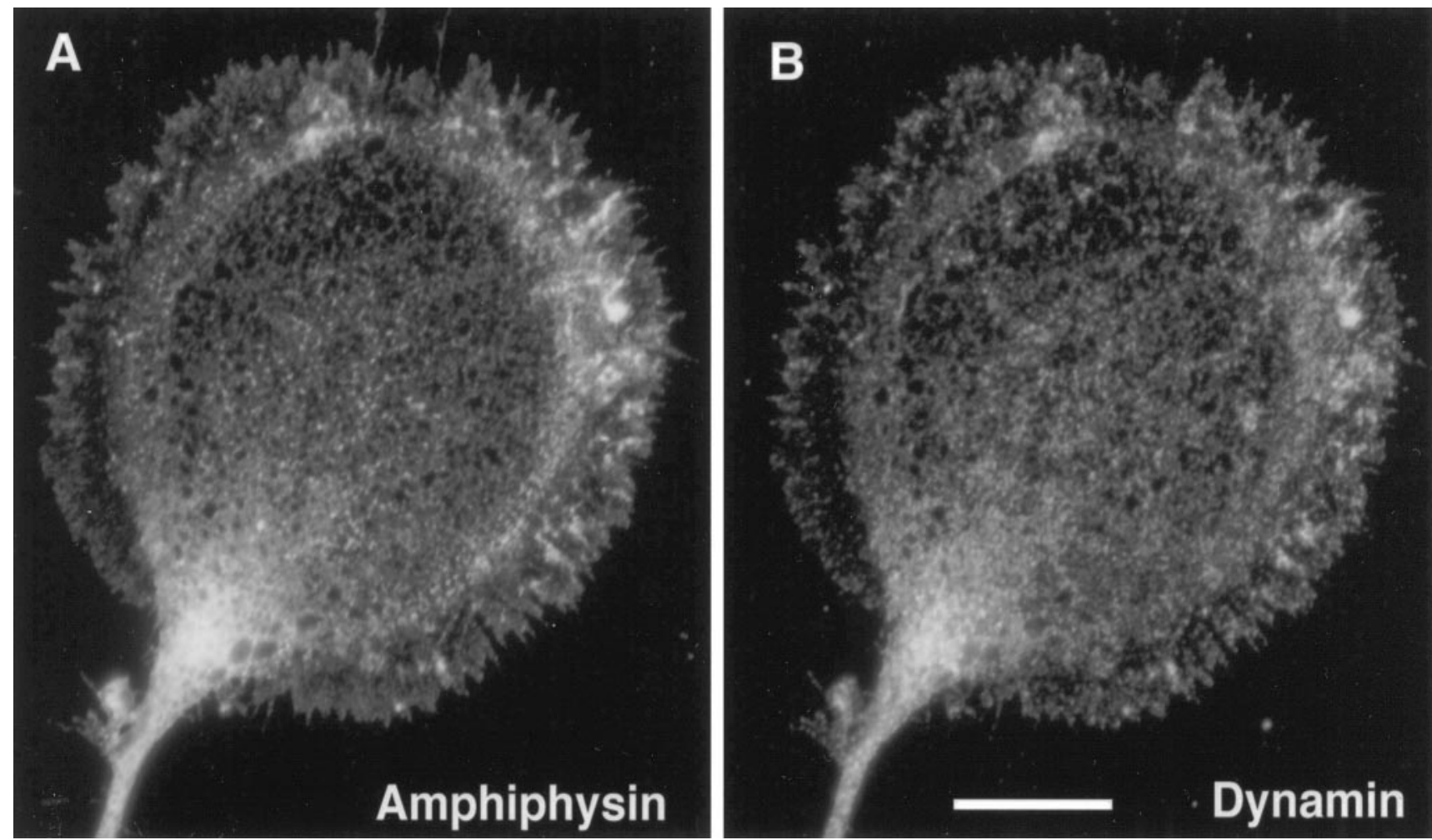

Figure 4. Distribution of amphiphysin I in the giant growth cone of an isolated neuron. $A, B$, High-power view of a giant growth cone double-stained for amphiphysin and for dynamin I. Amphiphysin I and dynamin I have a virtually identical localization and are concentrated in patches along the rim of the growth cone. Scale bar, $17 \mu \mathrm{m}$.

they form "hot spots" that have the localization typical of presynaptic compartments (Fig. 2a,b). Accordingly, these sites correspond to hot spots of immunoreactivity for synapsin I, a synaptic vesicle-associated protein (De Camilli et al., 1983a,b) (Fig. $2 c, d$ and $e, f)$. However, whereas synapsin I is strictly confined to well separated puncta representing synaptic vesicle clusters (Fletcher et al., 1991), amphiphysin I (Fig. 2e) and dynamin I (see Fig. $2 b)$ are present also in connecting axonal segments, possibly reflecting a soluble pool of these proteins (compare Fig. $2 e$ with $f$ ). This pool is clearly visible in cultures double-stained for the dendritic marker MAP2 and for amphiphysin I (Fig. 2g,h). In conclusion, the distribution of the amphiphysin I and dynamin I in "mature" neuronal cultures is very similar to the previously reported distribution of these proteins in brain tissue (McPherson et al., 1994; David et al., 1996) and validates the use of hippocampal neurons for the study of the function of amphiphysin I on neuronal development.

\section{Amphiphysin I is concentrated in growth cones of developing neurites}

The distribution of amphiphysin I in isolated developing neurons [stage 3 neurons according to the classification of Dotti et al. (1988)] is illustrated in Figure 3, which shows cultures stained for actin, amphiphysin I, and tubulin. Amphiphysin I is detectable in the perikaryon, dendritic tree, and distal axon. It is concentrated particularly at the tips of both axons (Fig. 3b) and dendrites (Fig. $3 b, e$ ), which also are enriched in actin (Fig. $3 a, d$ ). Similar observations were made for dynamin I (data not shown).

High-power observation revealed that the localization of amphiphysin I and dynamin I is virtually superimposable in both dendritic and axonal growth cones. This is illustrated clearly in
Figure 4, which shows the localization of the two proteins in one of the giant axonal growth cones that occasionally are found in hippocampal cultures (Mundigl et al., 1993). The large flat geometry of these growth cones makes them especially suitable for high-resolution light microscopy. Amphiphysin I and dynamin I are concentrated particularly in patches along the rim of the growth cone in the peripheral region that separates the organellerich core of the growth cone from the filopodia (Mundigl et al., 1993). These patches precisely coincide with patches of filamentous actin, as demonstrated by counterstaining with fluorescent phalloidin, a selective marker for F-actin (Fig. 5).

\section{Suppression of amphiphysin I expression inhibits neurite development}

We next used an antisense oligonucleotide approach to test the effect of the suppression of amphiphysin I expression on neurite outgrowth. To this aim we applied a new nucleic acid delivery system based on a polycationic amphipathic polymer that forms complexes with the negatively charged nucleic acid (Vinogradov et al., 1994). This method, which was never used previously on neurons, allows for the use of a substantially lower concentration of oligonucleotides than standard methods (50- to 100-fold lower), thus eliminating possible side effects and increasing the specificity. As shown in Figure $6 a$, a treatment of freshly plated neurons with antisense oligonucleotides for $48 \mathrm{hr}$ reduced the levels of amphiphysin I by $\sim 90 \%$ when compared with sense oligonucleotide-treated control cultures. No effect was observed by using a random oligo of the same nucleotide composition as the antisense oligo (data not shown). The treatment with antisense oligonucleotides did not affect the overall protein expression pattern of the neurons, as revealed by silver staining (Fig. 6b) 
Actin
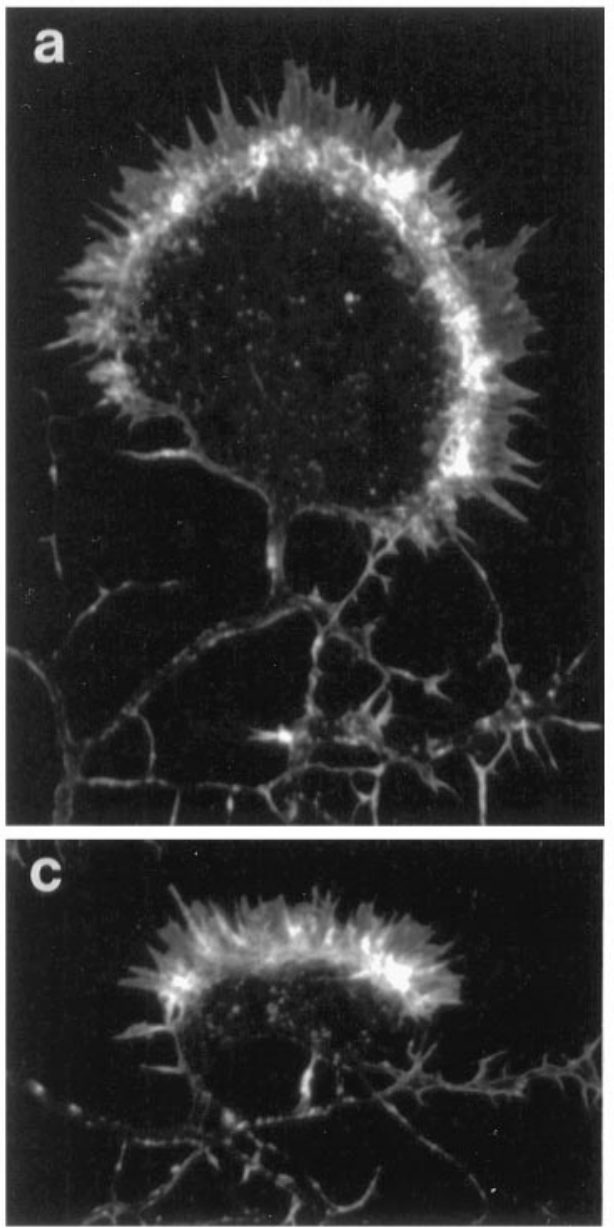

\section{Amphiphysin}
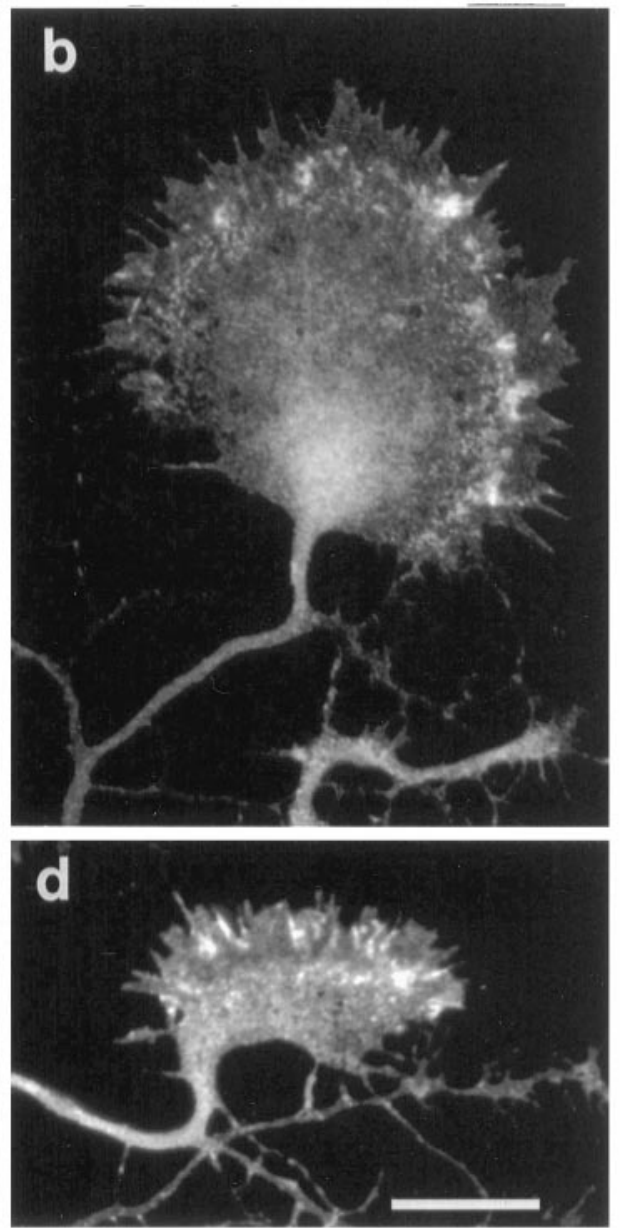

Figure 5. Colocalization of a pool of amphiphysin I with F-actin in giant growth cones. Shown is double staining with antiamphiphysin antibodies and phalloidin. The patches of intense amphiphysin immunoreactivity at the rim of the growth cone coincide with patches of F-actin. Scale bar, $17 \mu \mathrm{m}$. and by blotting for the housekeeping proteins tubulin and actin (Fig. 7A). These observations speak against a nonspecific cytopathic effect of the oligonucleotides on these cultures. A barely detectable decrease was observed in the levels of the synaptic vesicle protein synaptotagmin and of dynamin I (Fig. $7 B$ ), possibly reflecting a decrease in the state of differentiation of the neurons in the antisense-treated cultures. The effect of antisense treatment was reversible, because growth of neurites was observed after withdrawal of the antisense oligonucleotides.

The effect of antisense treatment on neuronal morphology was assessed by staining with antibodies directed against markers of the cytoskeleton (tubulin and actin) and a marker of the neuronal plasmalemma (syntaxin I) (Galli et al., 1995). Sense-treated neurons were indistinguishable from untreated cells. They had a long axonal process and several dendrites (Fig. 8a,c,d). Antisensetreated neurons had a very different morphology. In most cases they did not develop any process or had only a few short processes (Figs. 8b,e,f, 9d-f). Both axonal (Fig. 8b) and dendritic (Fig. 9) growth cones were completely absent. Furthermore, a profound disruption of the actin cytoskeleton was observed. Although in control (see Fig. 3) and sense-treated cultures (Figs. $8 d, 9 a, b$ ) the actin and amphiphysin I were concentrated at the tips of the dendritic and axonal growth cones, treatment with antisense oligonucleotides induced the collapse of the bulk of F-actin (Figs. $8 f, 9 d)$. The organization of the tubulin cytoskeleton did not seem to be affected (Figs. $8 b, 9 f$ ) beyond the obvious modification caused by altered cell shape.

Despite these changes, rhodamine-labeled transferrin, which is known to be internalized via clathrin-coated vesicles from the surface of perikarya and dendrites (Cameron et al., 1991), was taken up and concentrated in perinuclear spots in both sense- and antisense-treated neurons (Fig. 10). Likewise, fluid-phase uptake of horseradish peroxidase and uptake of wheat germ agglutinin was similar in sense- and antisense-treated cultures (data not shown).

\section{DISCUSSION}

Our results demonstrate that amphiphysin I plays a key role not only in the function of the mature presynaptic compartment but also in the development of axons. We report that the suppression of amphiphysin I expression in developing hippocampal neurons by antisense oligonucleotides has a potent inhibitory effect on neurite outgrowth and produces a collapse of growth cone. This phenotype mimics the effect previously shown to be produced by the suppression of dynamin I expression (Torre et al., 1994), thus providing further support to the hypothesis that the functions of amphiphysin I and dynamin I are interrelated (David et al., 1996). This hypothesis is strengthened by the close colocalization of dynamin I and amphiphysin I at all developmental stages.

The powerful inhibition of amphiphysin I expression was 
a

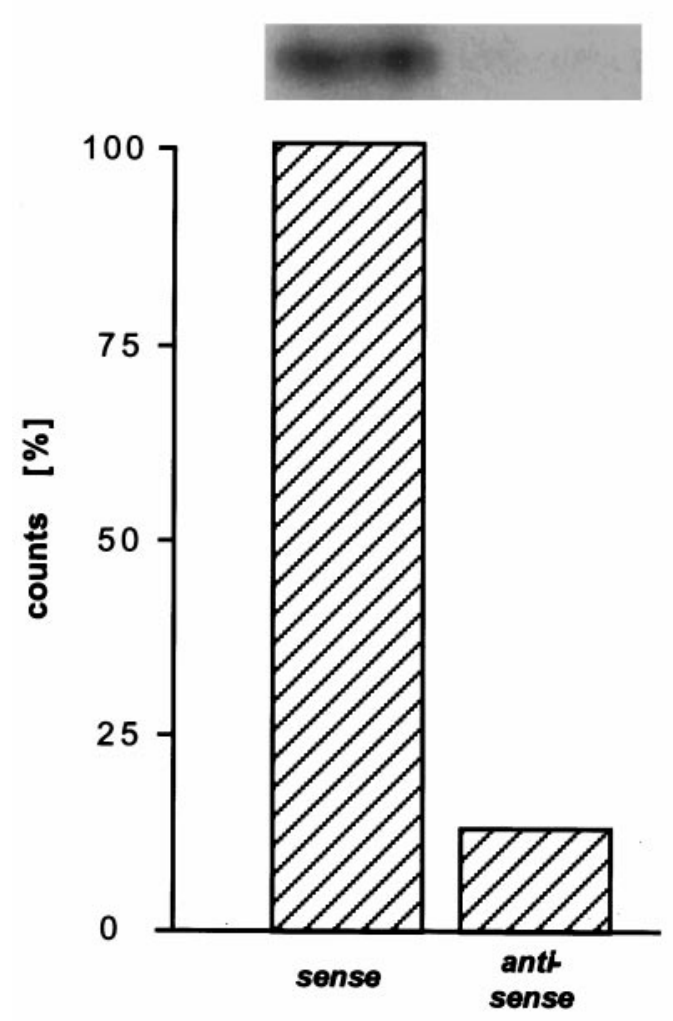

achieved by the use of a novel oligonucleotide delivery system based on a cationic compound that spontaneously forms watersoluble complexes with nucleic acids under physiological conditions (Vinogradov et al., 1994). This system allows for a very

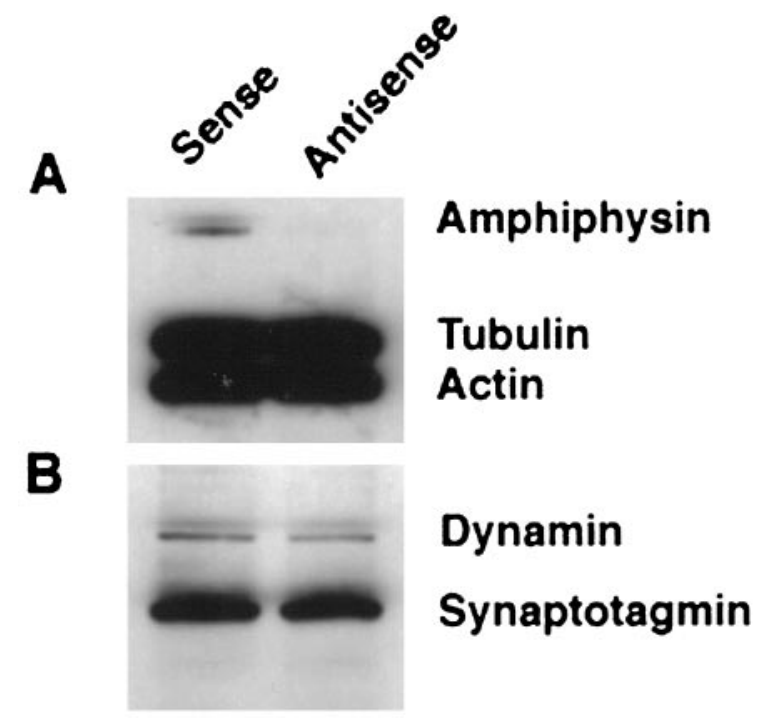

Figure 7. Western blot analysis of the expression levels of specific proteins in sense- and antisense-treated hippocampal neurons. $A$, Immunolabeling for amphiphysin tubulin and actin demonstrating that, despite the drastic effect on amphiphysin expression, there is no change in actin or tubulin expression. $B$, Immunolabeling for dynamin I and synaptotagmin demonstrating a slight decrease in the level of these two proteins.

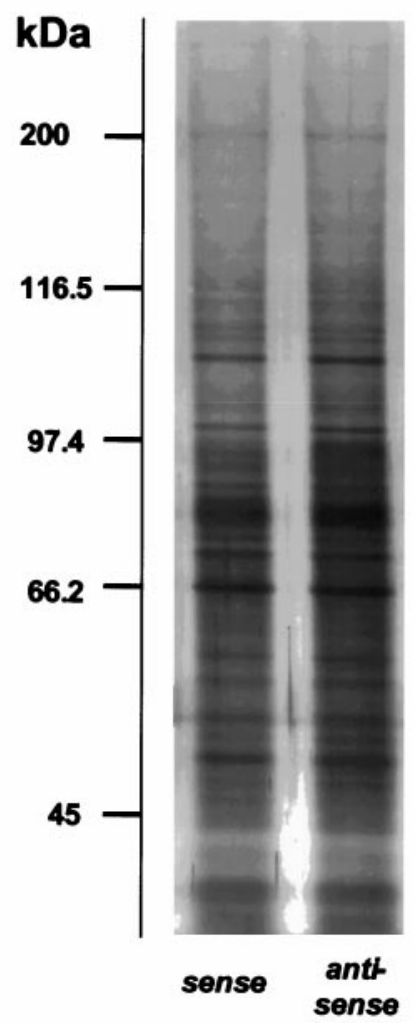

Figure 6. Inhibition of amphiphysin I expression by antisense oligonucleotides. $a$, Freshly plated hippocampal neurons were treated for $48 \mathrm{hr}$ with a $1.0 \mu \mathrm{M}$ concentration of either sense or antisense oligonucleotides, and then equal protein aliquots of the two cultures $(4 \mu \mathrm{g})$ were subjected to SDSPAGE $(7.5 \%)$ and Western blot analysis, using ${ }^{125}$ I-Protein A. An autoradiogram of the blot and the quantification of band radioactivities performed in a gamma counter are shown. $b$, Silver staining of gel lanes identical to those used for the Western blots, demonstrating that the overall protein expression pattern is not affected by antisense treatment. Proteins $(5 \mu \mathrm{g})$ were separated on a $5-15 \%$ gradient SDS-PAGE and were silver-stained.

substantial reduction (one to two orders of magnitude) in the concentration of oligonucleotides necessary to inhibit protein expression. As shown here, this oligonucleotide delivery system is very effective on neurons.

The mechanism by which amphiphysin I and dynamin I suppression block neurite outgrowth remains unclear. It is plausible that this effect may be accounted for, at least in part, by inhibition of membrane recycling at the cell surface. However, we did not observe a block in fluid-phase endocytosis nor of transferrin internalization by light microscopy cytochemistry. Because of the early state of differentiation of the antisense-treated neurons, synaptic vesicle endocytosis could not be assessed properly. An attractive possibility is that suppression of neurite outgrowth in amphiphysin I- and dynamin I-depleted neurons may reflect, at least in part, a role of amphiphysin I and dynamin I (either directly or via signaling cascades) in the function of the actin cytoskeleton.

An effect of dynamin I on actin function has been suggested by the block in the dynamics of cortical actin produced in fibroblasts by transfection of a mutant dynamin defective in GTP binding and hydrolysis (Damke et al., 1994). A relationship between amphiphysin I function and actin is suggested by studies on the yeast homologs of amphiphysin I, the Rvs167 and Rvs161 proteins (Crouzet et al., 1991; Sivadon et al., 1995). Rvs167 has a domain structure similar to amphiphysin, whereas Rvs161 represents a truncated form of amphiphysin/Rvs167 and includes only the coiled-coil NH2 terminal domain (David et al., 1994). Both of these yeast proteins have been shown by genetic studies to be involved in endocytosis (Munn et al., 1995). In addition, both 


\section{Sense}
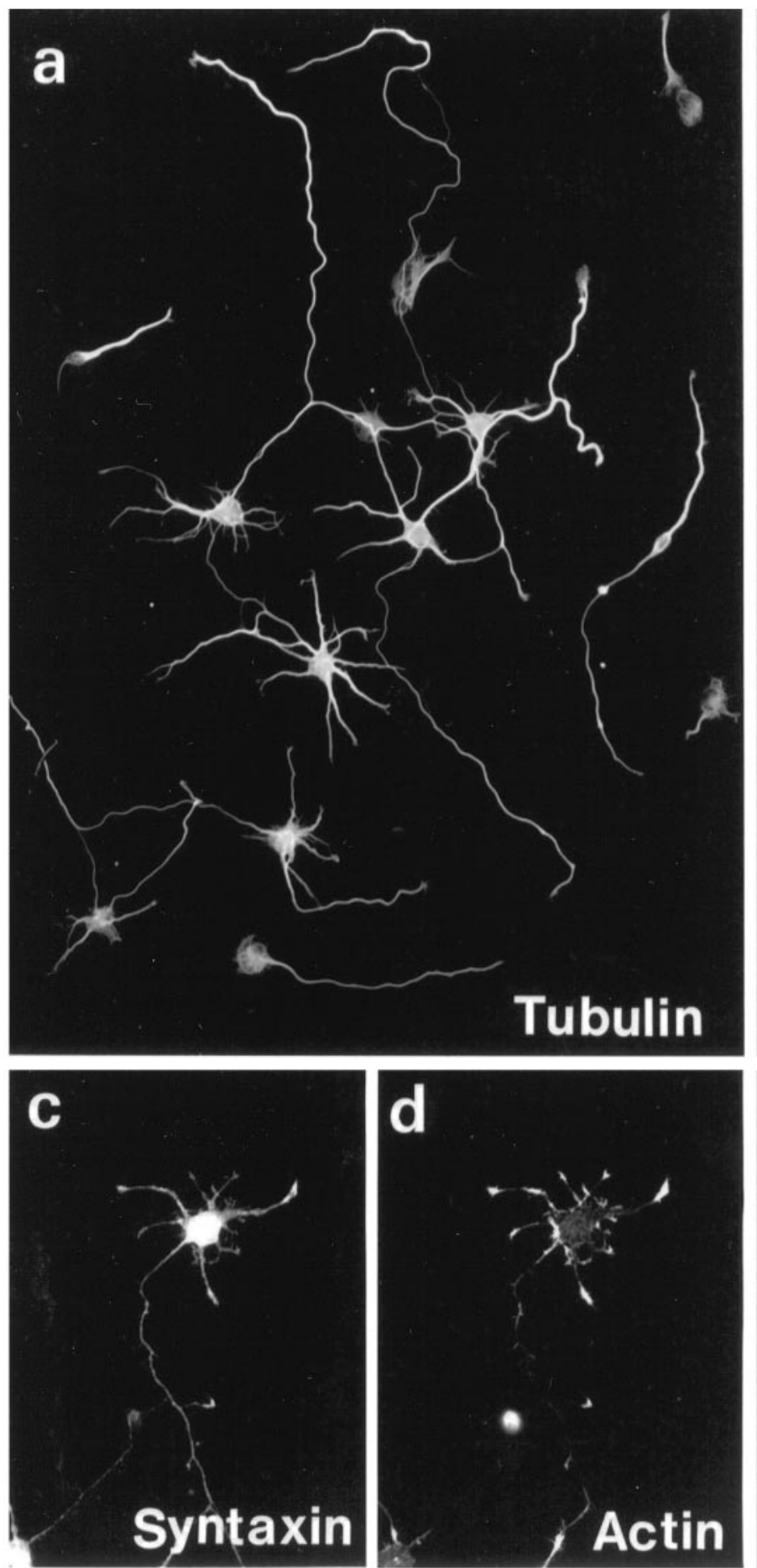
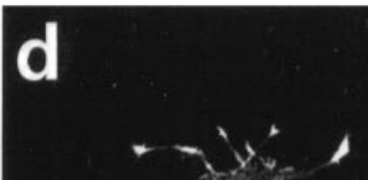

$-3$

$+$

9

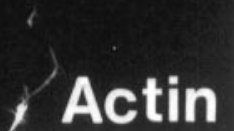

$1 \times 0^{4}$

\section{Antisense}

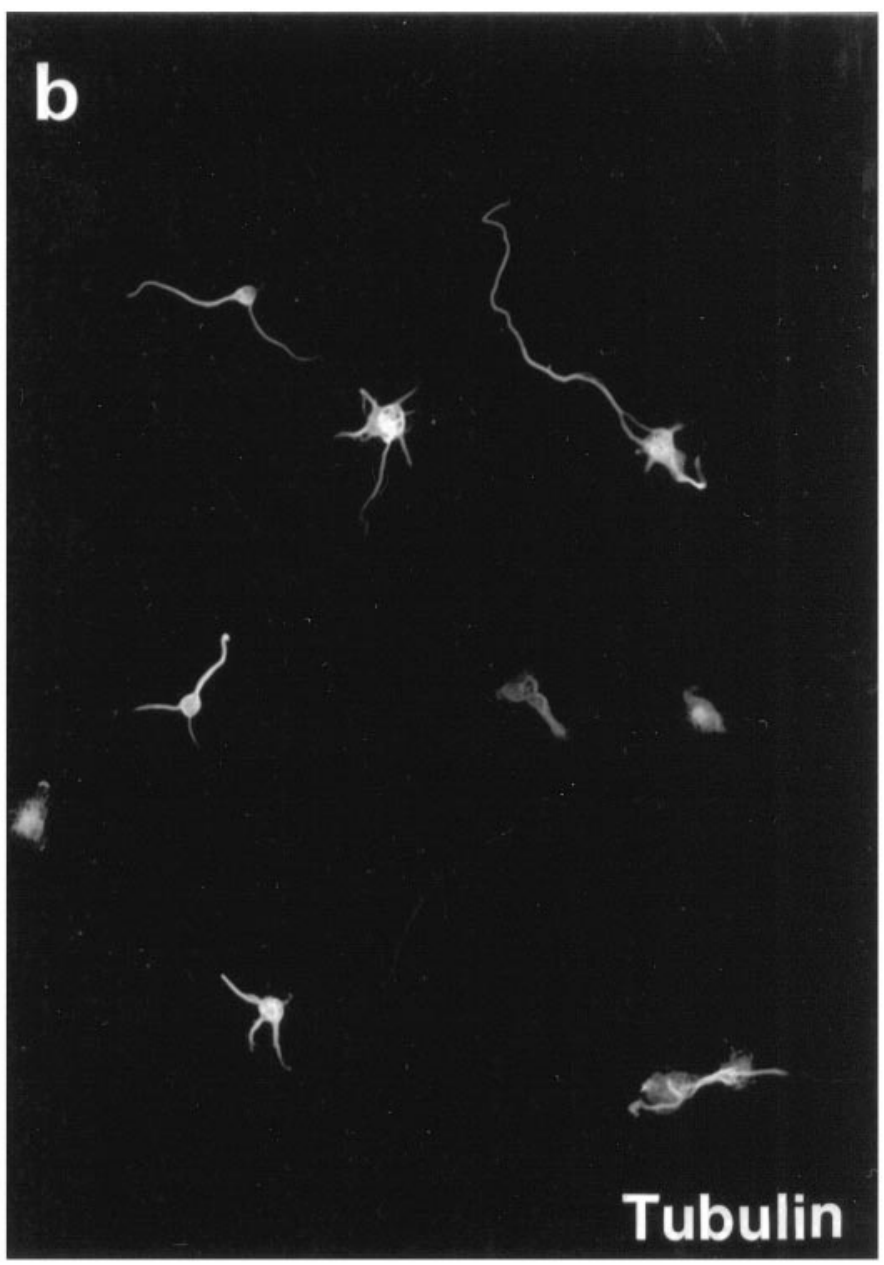

e
Syntaxin

\section{f}

$\boldsymbol{3}$

Q
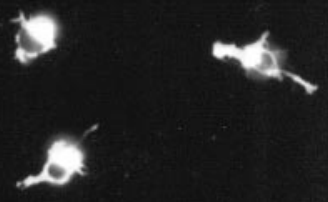

Actin

Figure 8. Amphiphysin I antisense oligonucleotides inhibit neurite development in hippocampal neurons in vitro. Neurons were treated for 48 hr with $1.0 \mu \mathrm{M}$ sense $(a, c, d)$ or antisense $(b, e, f)$ oligonucleotides and then processed for anti-tubulin $(a, b)$ immunofluorescence to reveal the overall cell morphology. Sense and antisense neurons also were double-labeled for syntaxin $(c, e)$ and actin $(d, f)$. Scale bar, $73 \mu \mathrm{m}$.

proteins have been linked to actin function by a variety of findings, which include genetic interaction between RVS161 and the actin gene (ACT1), effects of $R V S$ genes disruption on cell polarity, cell morphology, and localization of actin patches (Munn et al., 1995; Sivadon et al., 1995). Furthermore, an interaction be- tween Rvs167 and yeast actin has been demonstrated by a twohybrid screen, although it remains to be proven that this interaction is direct (Amberg et al., 1995). So far attempts to demonstrate a direct interaction between amphiphysin I with either G-actin or F-actin have proved unsuccessful (our unpub- 


\section{actin}
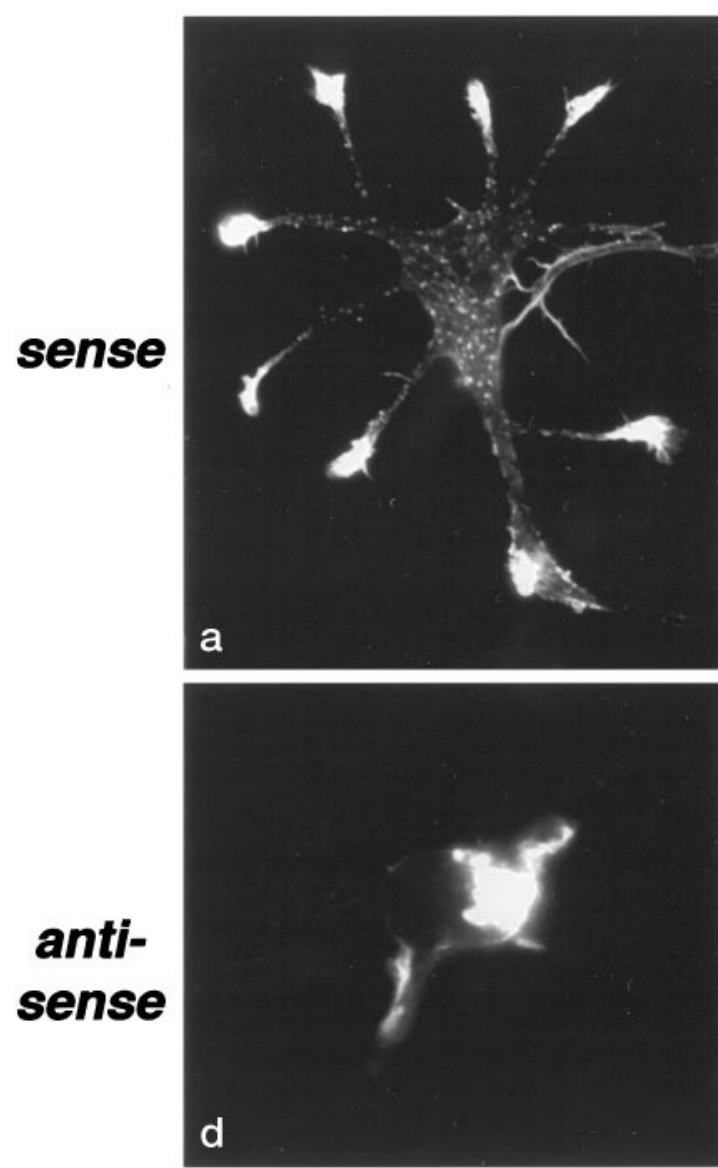

\section{amphiphysin}
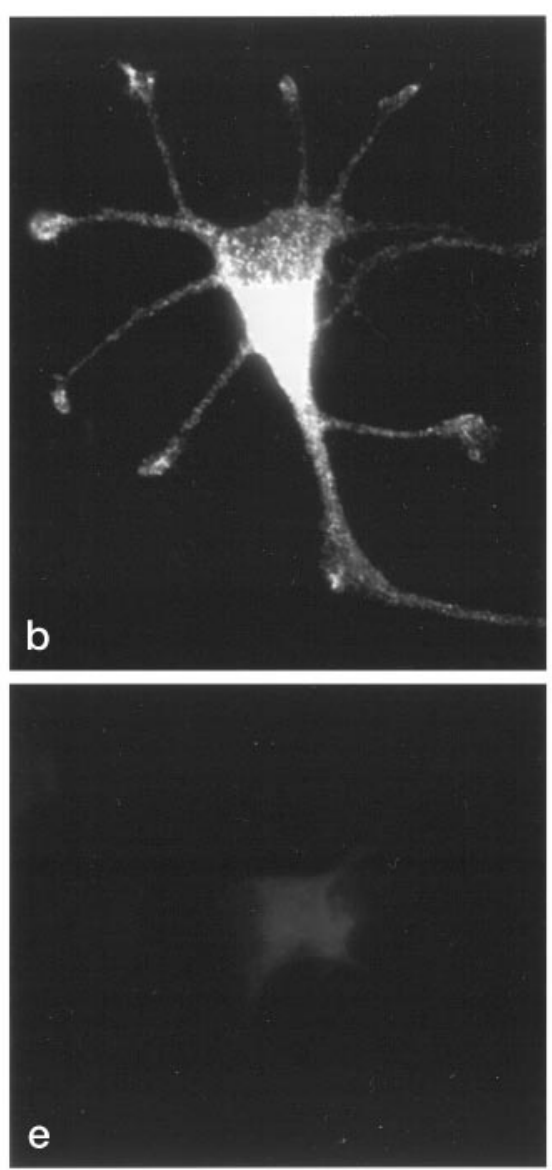

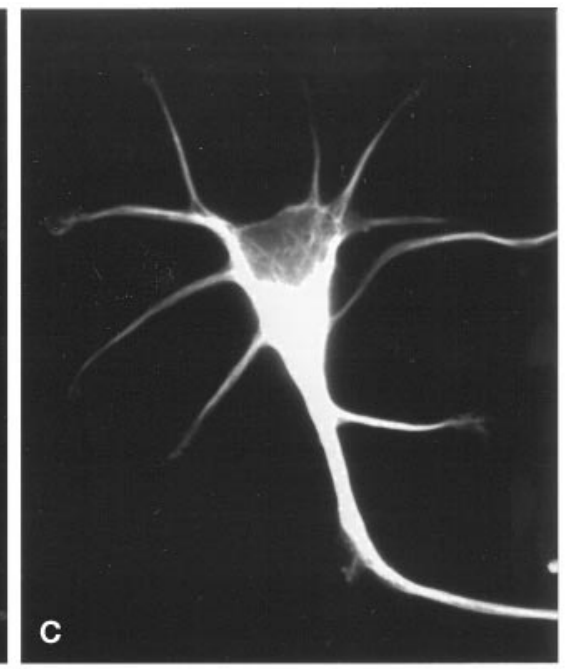

\section{tubulin}

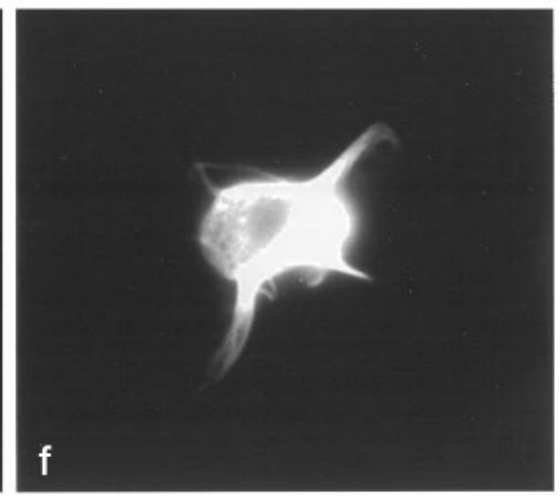

Figure 9. Amphiphysin I antisense oligonucleotide treatment induces a collapse of the actin cytoskeleton. Shown is triple immunofluorescence labeling for F-actin (TRITC phalloidin), amphiphysin I (DTAF), and $\beta$-tubulin (cascade blue). Actin and amphiphysin I accumulate at the tips of the growth cones in sense-treated cells $(a, b)$. Incubation with antisense oligonucleotides results in a collapse of F-actin into tangles primarily concentrated at one pole of the cell $(d)$. The residual levels of amphiphysin are barely detectable $(e)$, whereas the structural organization of the tubulin network appears normal $(c, f)$ beyond changes caused by different cell shape. Note the lack of actin at the tips of short cell processes visualized by tubulin immunostaining. Scale bar, $27 \mu \mathrm{m}$.

lished results). However, the close colocalization of a pool of amphiphysin I (and dynamin I) with actin patches demonstrated here supports a link between amphiphysin family members and the actin cytoskeleton. Amphiphysin may interact indirectly with actin via other proteins concentrated at actin patches. The other major neuronal binding partner, besides dynamin, for the SH3 domain of amphiphysin I is the inositol 5-phosphatase synaptojanin (McPherson et al., 1996). The property of synaptojanin to

\section{Sense}

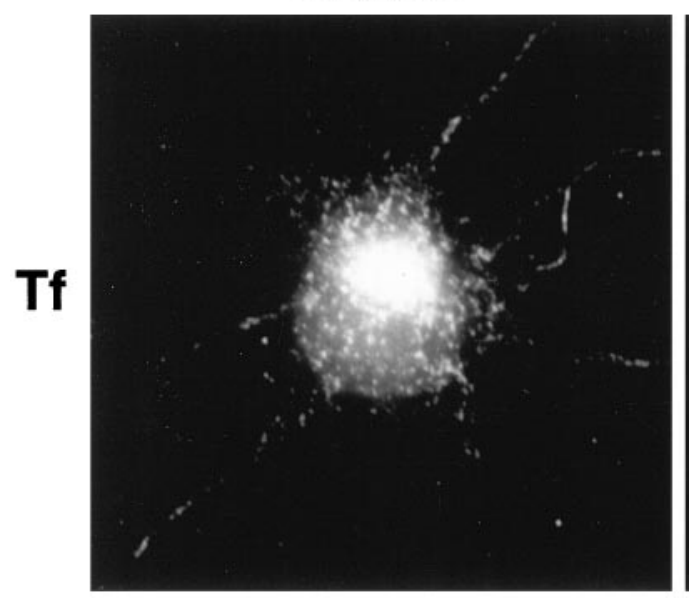

\section{Antisense}

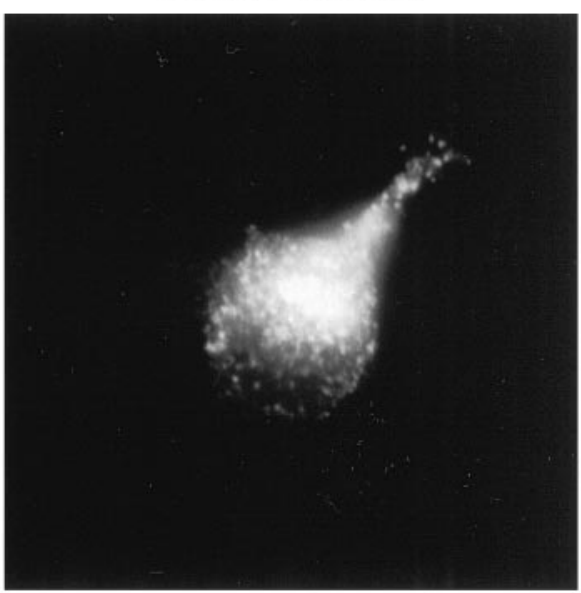

Figure 10. Uptake of fluorescent transferrin in sense- and antisense-treated hippocampal neurons. Transferrin uptake is not inhibited in the antisense-treated neuron. Note the presence of numerous dendrites in the sense- but not in the antisense-treated neurons. 
cleave phosphoinositides (McPherson et al., 1996; Woscholski et al., 1997), which are potent regulators of actin function (Janmey, 1994), may reflect another indirect relationship between amphiphysin and actin.

The establishment of axonal polarity in neurons is controlled at least partially by the same fundamental mechanisms that control polarity in yeast (Luo et al., 1994, 1997; Drubin and Nelson, 1996). It is therefore of interest that the suppression of Rvs/ amphiphysin function impairs polarity in yeast and neurite extension in neurons. Both of these effects may be achieved by similar mechanisms involving the actin cytoskeleton. We note that an inhibition of neurite outgrowth also was observed after treatment of neuronal hippocampal cultures with antisynapsin II antisense oligonucleotides (Ferreira et al., 1994). Synapsin is an actin-binding protein that participates in the synaptic vesicle cycle (De Camilli et al., 1990). Thus, a dual function in neuritogenesis and presynaptic function appears to be a property shared by a variety of cytosolic presynaptic proteins.

A possible connection between amphiphysin function and the cortical actin cytoskeleton raises the question of whether the function of amphiphysin I in endocytosis involves actin. Studies in yeast have demonstrated that many other genes, besides RVS genes, play a dual role in endocytosis and actin function. For example, the genes END3, END4, END5, END7, and SAC6 are required both for endocytosis and for correct actin localization (Kübler and Riezman, 1993; Raths et al., 1993; Benedetti et al., 1994; Munn et al., 1995). One such gene, END7, is the actin gene itself (ACT1) (Munn et al., 1995). SAC6 and END4 are similar to the mammalian actin-binding proteins fibrin and talin, respectively (Adams et al., 1995; Brower et al., 1995; Munn et al., 1995). Conversely, it was found recently that mutations in one of the actin motors, the myosin protein Myo5, produces endocytosis defects (Geli and Riezman, 1996). Several studies have shown that even in mammalian cells actin plays an important role in endocytosis. An involvement of actin is well documented in fluid-phase endocytosis (Schmalzing et al., 1995; Lamaze et al., 1996), but growing evidence suggests that actin participates in clathrin-mediated endocytosis also (Gottlieb et al., 1993; Evangelisti et al., 1995; Durrbach et al., 1996). Further studies of amphiphysin I and of the amphiphysin protein family may help to shed new light on growth cone dynamics and on the molecular mechanisms implicated in the still elusive connection between actin and endocytosis.

\section{REFERENCES}

Adams AE, Shen W, Lin CS, Leavitt J, Matsudaira P (1995) Isoformspecific complementation of the yeast sac6 null mutation by human fimbrin. Mol Cell Biol 15:69-75.

Amberg DC, Basart E, Botstein D (1995) Defining protein interactions with yeast actin in vivo. Nat Struct Biol 2:28-35.

Banker GA, Cowan WM (1977) Rat hippocampal neurons in dispersed cell culture. Brain Res 126:397-425.

Baverfeind R, Takei K, DeCamilli P (1998) Amphiphysin I is associated with coated endocytic intermediates and undergoes stimulationdepended dephosphorylation in nerve terminals. J Biol Chem, in press.

Benedetti H, Raths S, Crausaz F, Riezman H (1994) The END3 gene encodes a protein that is required for the internalization step of endocytosis and for actin cytoskeleton organization in yeast. Mol Biol Cell 5:1023-1037.

Brower SM, Honts JE, Adams AE (1995) Genetic analysis of the fimbrin-actin binding interaction in Saccharomyces cerevisiae. Genetics 140:91-101.

Butler MH, David C, Ochoa G-C, Freyberg Z, Daniell L, Grabs D, Cremona O, De Camilli P (1997) Amphiphysin II (SH3P9; BIN1), a member of the amphiphysin/RVS family, is localized in the cortical cytomatrix of axon initial segments and nodes of Ranvier in brain and around T-tubules in skeletal muscle. J Cell Biol 137:1355-1367.

Cameron PL, Sudhof TC, Jahn R, De Camilli P (1991) Colocalization of synaptophysin with transferrin receptors: implications for synaptic vesicle biogenesis. J Cell Biol 115:151-164.

Crouzet M, Urdaci M, Dulau L, Aigle M (1991) Yeast mutant affected for viability upon nutrient starvation: characterization and cloning of the RVS161 gene. Yeast 7:727-743.

Damke H, Baba T, Warnock DE, Schmid SL (1994) Induction of mutant dynamin specifically blocks endocytic coated vesicle formation. J Cell Biol 127:915-934.

David C, Solimena M, De Camilli P (1994) Autoimmunity in stiff-man syndrome with breast cancer is targeted to the $\mathrm{C}$-terminal region of human amphiphysin, a protein similar to the yeast proteins, Rvs167 and Rvs161. FEBS Lett 351:73-79.

David C, McPherson PS, Mundigl O, De Camilli P (1996) A role of amphiphysin in synaptic vesicle endocytosis suggested by its binding to dynamin in nerve terminals. Proc Natl Acad Sci USA 93:331-335.

De Camilli P, Takei K (1996) Molecular mechanisms in synaptic vesicle endocytosis and recycling. Neuron 16:481-486.

De Camilli P, Cameron R, Greengard P (1983a) Synapsin I (protein I) a nerve terminal-specific phosphoprotein. Its general distribution in synapses of the central and peripheral nervous system demonstrated by immunofluorescence in frozen and plastic sections. J Cell Biol 96:1337-1354.

De Camilli P, Harris Jr SM, Huttner WB, Greengard P (1983b) Synapsin I (protein I), a nerve terminal-specific phosphoprotein. J Cell Biol 96:1355-1373.

De Camilli P, Benfenati F, Valtorta F, Greengard P (1990) The synapsins. Annu Rev Cell Biol 6:433-460.

De Camilli P, Thomas A, Cofiell R, Folli F, Lichte B, Piccolo G, Meinck HM, Austoni M, Fassetta G, Bottazzo G, Bates D, Cartlidge N, Solimena M, Kiliman MW (1993) The synaptic vesicle-associated protein amphiphysin is the $128 \mathrm{kDa}$ autoantigen of stiff-man syndrome with breast cancer. J Exp Med 178:2219-2223.

Dotti CG, Sullivan CA, Banker GA (1988) The establishment of polarity by hippocampal neurons in culture. J Neurosci: 8:1454-1468.

Drubin DG, Nelson WJ (1996) Origins of cell polarity. Cell 84:335-344.

Durrbach A, Louvard D, Coudrier E (1996) Actin filaments facilitate two steps of endocytosis. J Cell Sci 109:457-465.

Evangelisti R, Becchetti E, Baroni R, Rossi L, Arena N, Valeno V, Carinci P, Locci P (1995) Modulation of phenotypic expression of fibroblasts by alteration of the cytoskeleton. Cell Biochem Funct 13:41-52.

Ferreira A, Kosik KS, Greengard P, Han HQ (1994) Aberrant neurites and synaptic vesicle protein deficiency in synapsin II-depleted neurons. Science 264:977-979.

Fletcher TL, Cameron P, De Camilli P, Banker G (1991) The distribution of synapsin I and synaptophysin in hippocampal neurons developing in culture. J Neurosci 11:1617-1626.

Folli F, Solimena M, Cofiell R, Austoni M, Tallini G, Fassetta G, Bates D, Cartlidge N, Bottazzo GF, Piccolo G, De Camilli P (1993) Autoantibodies to a 128-kd synaptic protein in three women with the stiff-man syndrome and breast cancer. N Engl J Med 328:546-551.

Galli T, Garcia EP, Mundigl O, Chilcote TJ, De Camilli P (1995) v- and t-SNAREs in neuronal exocytosis: a need for additional components to define sites of release. Neuropharmacology 34:1351-1360.

Geli MI, Riezman H (1996) Role of type I myosin in receptor-mediated endocytosis in yeast. Science 272:533-535.

Goslin K, Banker GA, editors (1990) Rat hippocampal neurons in lowdensity culture. Cambridge, MA: MIT.

Gottlieb TA, Ivanov IE, Adesnik M, Sabatini DD (1993) Actin microfilaments play a critical role in endocytosis at the apical but not the basolateral surface of polarized epithelial cells. J Cell Biol 120:695-710.

Grabs D, Slepnev VI, Songyang Z, David C, Lynch M, Cantley LC, De Camilli P (1997) The SH3 domain of amphiphysin binds the prolinerich domain of dynamin at a single site that defines a new SH3 binding consensus sequence. J Biol Chem 272:13419-13425.

Hinshaw JE, Schmid SL (1995) Dynamin self-assembles into rings suggesting a mechanism for coated vesicle budding. Nature 374:190-192.

Janmey PA (1994) Phosphoinositides and calcium as regulators of cellular actin assembly and disassembly. Annu Rev Physiol 56:169-191.

Kabanov AV, Vinogradov SV, Suzdaltseva YG, Alakhov VY (1995) 
Water-soluble block polycations as carriers for oligonucleotide delivery. Bioconjug Chem 6:639-643.

Kabanov AV, Bronich TK, Kabanov VA, Yu K, Eisenberg A (1996) Soluble stoichiometric complexes from poly( $N$-ethyl-4-vinylpyridinium) cations and poly(ethylene oxide) block polymethacrylate anions. Macromolecules 29:8999.

Koenig JH, Ikeda K (1989) Disappearance and reformation of synaptic vesicle membrane upon transmitter release observed under reversible blockage of membrane retrieval. J Neurosci 9:3844-3860.

Kübler E, Riezman H (1993) Actin and fimbrin are required for the internalization step of endocytosis in yeast. EMBO J 12:2855-2862.

Kyhse-Andersen J (1994) Electroblotting of multiple gels: a simple apparatus without buffer tank for rapid transfer of proteins from polyacrylamide to nitrocellulose. J Biochem Biophys Methods 10:203-209.

Laemmli UK (1970) Cleavage of structural proteins during the assembly of the head of bacteriophage T4. Nature 227:680-685.

Lamaze C, Chuang TH, Terlecky LJ, Bokoch GM, Schmid SL (1996) Regulation of receptor-mediated endocytosis by Rho and Rac. Nature 382:177-179.

Leprince C, Romero R, Cussac D, Vayssiere B, Berger R, Tavitian A, Camonis JH (1997) A new member of the amphiphysin family connecting endocytosis and signal transduction pathways. J Biol Chem 272:15101-15105.

Lichte B, Veh RW, Meyer HE, Kiliman MW (1992) Amphiphysin, a novel protein associated with synaptic vesicles. EMBO J 11:2521-2530.

Luo L, Liaou YJ, Jan LY, Jan YN (1994) Distinct morphogenetic functions of similar small GTPases; Drosophila Drrac1 is involved in axonal outgrowth and myoblast fusion. Genes Dev 8:1787-1802.

Luo L, Jan LY, Jan YN (1997) Rho family GTP-binding proteins in growth cone signalling. Curr Opin Neurobiol 7:81-86.

Masur SK, Kim YT, Wu CF (1990) Reversible inhibition of endocytosis in cultured neurons from the Drosophila temperature-sensitive mutant shibire ts1. J Neurogenet 6:191-206.

McPherson PS, Czernik AJ, Chilcote TJ, Onofri F, Benfenati F, Greengard P, Schlessinger J, De Camilli P (1994) Interaction of Grb2 via its Src homology 3 domains with synaptic proteins including synapsin I. Proc Natl Acad Sci USA 91:6486-6490.

McPherson PS, Garcia EP, Slepnev VI, David C, Zhang XM, Grabs D, Sossin WS, Bauerfeind R, Nemoto Y, De Camilli P (1996) A presynaptic inositol 5-phosphatase. Nature 379:353-357.

Mundigl O, Matteoli M, Daniell L, Thomas-Reetz A, Metcalf A, Jahn R, De Camilli P (1993) Synaptic vesicle proteins and early endosomes in cultured hippocampal neurons: differential effects of brefeldin A in axon and dendrites. J Cell Biol 122:1207-1221.

Mundigl O, Verderio C, Kraszewski K, De Camilli P, Matteoli M (1995) A radioimmunoassay to monitor synaptic activity in hippocampal neurons in vitro. Eur J Cell Biol 66:246-256.

Munn AL, Stevenson BJ, Geli MI, Riezman H (1995) end5, end6, and end7: mutations that cause actin delocalization and block the internalization step of endocytosis in Saccharomyces cerevisiae. Mol Biol Cell 6:1721-1742.

Ramjaun AR, Micheva KD, Bouchelet I, McPherson PS (1997) Identification and characterization of a nerve terminal-enriched amphiphysin isoform. J Biol Chem 272:16700-16706.

Raths S, Rohrer J, Crausaz F, Riezman H (1993) end3 and end4: two mutants defective in receptor-mediated and fluid-phase endocytosis in Saccharomyces cerevisiae. J Cell Biol 120:55-65.

Robinson PJ, Sontag JM, Liu JP, Fykse EM, Slaughter C, McMahon H, Sudhof TC (1993) Dynamin GTPase regulated by protein kinase C phosphorylation in nerve terminals. Nature 365:163-166.

Sakamuro D, Elliott KJ, Wechsler-Reya R, Prendergast GC (1996) $\mathrm{BIN} 1$ is a novel MYC-interacting protein with features of a tumor suppressor. Nat Genet 14:69-77.

Schmalzing G, Richter HP, Hansen A, Schwarz W, Just I, Aktories K (1995) Involvement of the GTP binding protein Rho in constitutive endocytosis in Xenopus laevis oocytes. J Cell Biol 130:1319-1332.

Shupliakov O, Low P, Grabs D, Gad H, Chen H, David C, Takei K, De Camilli P, Brodin L (1997) Synaptic vesicle endocytosis impaired by disruption of dynamin-SH3 domain interactions. Science 276:259-263.

Sivadon P, Bauer F, Aigle M, Crouzet M (1995) Actin cytoskeleton and budding pattern are altered in the yeast rvs161 mutant: the Rvs161 protein shares common domains with the brain protein amphiphysin. Mol Gen Genet 246:485-495.

Sparks JD, Phung TL, Bolognino M, Charles E (1996) Insulin-mediated inhibition of apolipoprotein $\mathrm{B}$ secretion requires an intracellular trafficking event and phosphatidylinositol 3-kinase activation: studies with brefeldin $\mathrm{A}$ and wortmannin in primary cultures of rat hepatocytes. Biochem J 313:567-574.

Takei K, McPherson PS, Schmid SL, De Camilli P (1995) Tubular membrane invaginations coated by dynamin rings are induced by GTP $\gamma$ S in nerve terminals. Nature 374:186-190.

Takei K, Mundigl O, Daniell L, De Camilli P (1996) The synaptic vesicle cycle: a single vesicle budding step involving clathrin and dynamin. J Cell Biol 133:1237-1250.

Torre E, McNiven MA, Urrutia R (1994) Dynamin 1 antisense oligonucleotide treatment prevents neurite formation in cultured hippocampal neurons. J Biol Chem 269:32411-32417.

Vinogradov SV, Suzdaltseva Y, Alakhov VY, Kabanov AV (1994) Inhibition of herpes simplex virus 1 reproduction with hydrophobized antisense oligonucleotides. Biochem Biophys Res Commun 203:959-966.

Woscholski R, Finan PM, Radley E, Totty NF, Sterling AE, Hsuan JJ, Waterfield MD, Parker PJ (1997) Synaptojanin is the major constitutively active phosphatidylinositol-3,4,5-trisphosphate 5-phosphatase in rodent brain. J Biol Chem 272:9625-9628. 